\title{
Recent Dutch-Language Publications
}

\author{
Harry A. Poeze \\ KITLV/Royal Netherlands Institute of Southeast Asian and Caribbean Studies \\ Poeze@kitlv.nl
}

Willem Oosterbeek, Nootmuskaat: De geschiedenis van een wonderbaarlijk nootje. Amsterdam: Atheneum-Polak \& Van Gennep, 2017, 165 pp. ISBN 9789025303884. Price: EUR 15.00 (paperback).

Nutmeg and mace (the spice made from the covering of the nutmeg seed) drove much of the European expansion to the Indies. From the ninth century on, there are scattered references to nutmeg in European sources. Slowly it became an expensive luxury good, partly because it could only reach Europe after a long journey. After the Portuguese settled in Southheast Asia more became known about nutmeg, which was only cultivated on six islands of the Banda Archipelago in East Indonesia. Portuguese first visited Banda in 1512, and made great profits with the spice trade: nutmeg was often mentioned as worth its weight in gold. The rising force of the Netherlands was eager to extend its European trade empire to the East, lured by the potential profits in spices. In 1599, the first Dutch ship anchored in Banda, marking the beginning of a difficult relationship between the local gentry and the Dutch intruders, who strove for a monopoly in nutmeg. The local owners, of course, looked for freedom to trade and bargain for the best price. The Dutch ousted the Portuguese, Spaniards, and British from Banda. The Banda-Dutch encounters often became violent, with a lot of casualties on both sides. To break the deadlock in 1621 voc Governor General Jan Pieterszoon Coen opted for drastic action. In what became known as the Banda massacre the entire local population was killed, driven out, or enslaved. The monopoly was established, and Banda became a nutmeg plantation, with 68 overseers, carefully selected by the voc, and 1,700 slaves, responsible for production. These overseers were exploited again by the voc, who impoverished them. voc kept its monopoly intact for almost two centuries. More than twenty percent of its turnover derived from the spices, with nutmeg, after pepper, cloves, and cinnamon, as the most lucrative.

Journalist and writer Willem Overbeek came upon the nutmeg story and produced Nootmuskaat, in which he modestly relates the history of the world-

(C) HARRY A. POEZE, 2017 | DOI: 10.1163/22134379-17304006

This is an open access article distributed under the terms of the prevailing CC-BY-NC license 
wide impact of nutmeg. He adds to this chapters on the cultivation method, and its use in Europe. In a medical handbook published around 180o, for instance, it was described as a cure for 138 ailments, and was used as a perfume, love potion, and drug. Overbeek also records the downfall of Banda. It has long lost its unique selling position; today one plantation remains as a kind of memento. The author's impressions of contemporary Banda fill the last chapter, where he mentions there are minor prospects for heritage tourism. In all, this book is well documented (except for a missing map) and makes good reading for a general audience.

Hendrik E. Niemeijer and Th. van den End, with the collaboration of G.J. Schutte (editors), Bronnen betreffende kerk en school in het gouvernement Ambon ten tijde van de Verenigde Oost-Indische Compagnie 1605-169o. Eerste deel, Band 1. Den Haag: Huygens ING, 2015, 593 pp. [Rijks Geschiedkundige Publicatiën, Grote Serie 264]. ISBN 9789052161846. Price: EUR 59.0o (together with Band 2); for all volumes: 140.00 (paperback).

Hendrik E. Niemeijer and Th. van den End, with the collaboration of G.J. Schutte (editors), Bronnen betreffende kerk en school in het gouvernement Ambon ten tijde van de Verenigde Oost-Indische Compagnie 1690-1791. Eerste deel, Band 2. Den Haag: Huygens ING, 2015, 575 pp. [Rijks Geschiedkundige Publicatiën, Grote Serie 265]. ISBN 9789052161853. Price: EUR 59.00 (together with Band 1); for all volumes: 140.00 (paperback).

Hendrik E. Niemeijer and Th. van den End, with the collaboration of G.J. Schutte (editors), Bronnen betreffende kerk en school in het gouvernement Ternate ten tijde van de Verenigde Oost-Indische Compagnie 1612-1697; Tweede deel, Band 1. Den Haag: Huygens ING, 2015, 428 pp. [Rijks Geschiedkundige Publicatiën, Grote Serie 266]. ISBN 978905216186o. Price: EUR 49.00 (together with Band 1); for all volumes: 140.00 (paperback).

Hendrik E. Niemeijer and Th. van den End, with the collaboration of G.J. Schutte (editors), Bronnen betreffende kerk en school in het gouvernement Ternate ten tijde van de Verenigde Oost-Indische Compagnie 1698-1791. Tweede deel, Band 2. Den Haag: Huygens ING, 2015, 401 pp. ISBN 9789052161877. [Rijks Geschiedkundige Publicatiën, Grote Serie 267]. Price: EUR 49.00 (together with Band 1); for all volumes: 140.00 (paperback).

Hendrik E. Niemeijer and Th. van den End, with the collaboration of G.J. Schutte (editors), Bronnen betreffende kerk en school in het gouvernement Banda ten 
tijde van de Verenigde Oost-Indische Compagnie 1625-1790; Derde deel. Den Haag: Huygens ING, 2015, 536 pp. [Rijks Geschiedkundige Publicatiën, Grote Serie 268]. ISBN 9789052161884. Price: EUR 34.oo; for all volumes:140.00 (paperback).

Hendrik E. Niemeijer and Th. van den End, with the collaboration of G.J. Schutte (editors), Bronnen betreffende kerk en school in de gouvernementen Ambon, Ternate en Banda ten tijde van de Verenigde Oost-Indische Compagnie 1605-1791. Vierde deel, Inleiding, bijlagen en registers. Den Haag: Huygens ING, 2015, 386 pp. [Rijks Geschiedkundige Publicatiën, Grote Serie 269]. ISBN 9789052161891. Price: EUR 28.oo; for all volumes: 140.00 (paperback).

Three prominent historians of Protestantism in the Indies have achieved a rare accomplishment: in 2912 pages spanning 6 volumes and including 857 documents this volume offers troves of original information on the Protestant Church in East Indonesia, where three ministers were stationed in Ambon, Ternate, and Banda. They were supervised by the Church in Batavia, which in turn was subservient to the voc administration. The ministers were assisted by ziekentroosters (assistant ministers) and schoolmasters. This last category consisted of indigenes, while the other two were European. Their parishes consisted of a small minority of European inhabitants and indigenous believers, who upon the voc eviction of the Portuguese from the area in 1605 changed from Catholics to Protestants. Malay thus became the church language, which resulted in many publications in Malay, which in turn gave an important impetus to its standardization.

The documents consist of minutes, correspondence, visitation reports, files on ministers, and financial accounts. These were not readily available, but had to be collected, or even discovered, in a range of archives. Most originate from the Batavia Church Council Archive, now in Jakarta, supplemented by documents from The Hague, Amsterdam, and Hoorn. The Project was first proposed in 1995, and started two years later. Small wonder it took more time than anticipated, with the contents three times as voluminous as planned. The documents are annotated where necessary. The work of the editors is reflected in the fourth volume, and attests to their expertise. A lot of research results in more than the extensive indexes. Included are lists of ministers, assistant ministers, and schoolmasters, as well as the instructions and the Church Order they had to obey. The list of Malay texts and publications, supplemented with a lot of additional information, is fascinating. The overall result is thus exemplary. A digital edition of the series is available via resources .huygens.knaw.nl/retroboeken/molukse_kerk 
Martine Gosselink, Maria Holtrop and Robert Ross (editors), Goede Hoop. ZuidAfrika en Nederland vanaf 1600 . Nijmegen: Vantilt, Amsterdam: Rijksmuseum, 2017, 384 pp. ISBN 9789460043123. Price: EUR 34.50 (hardback).

Martine Gosselink, Maria Holtrop and Robert Ross (editors), Good Hope. South Africa and the Netherlands from 1600 . Nijmegen: Vantilt, Amsterdam: Rijksmuseum, 2017, 384 pp. ISBN 978946oo4313o. Price: EUR 34.50 (hardback).

Bas Kromhout, Goede Hoop. 400 jaar Nederland en Zuid-Afrika. Zutphen: WalburgPers, Hilversum: NTR, 2017, 16o pp. ISBN 97894624918og. Price: EUR 24.95 (hardback).

In 2013, the Rijksmuseum in Amsterdam started a prestigious series based on its extensive 'overseas' collections that explore the history and heritage the Netherlands shares with places such as Indonesia, Japan, China, Sri Lanka, and Ghana. The most recent addition has South Africa as its subject. Titles on Suriname and India are forthcoming, and each new title in this series is accompanied by a Rijksmuseum exhibition, like this one on Dutch-South Africa connections which ran from February to May 2017. The titles, published both in Dutch and English, differ as to their plan. Some are written by single authors, some by two and others are edited volumes. The treatment varies from descriptive to analytical, and in terms of length, Goede Hoop/Good Hope diverts from its predecessors. Three editors collected articles and short essays by 27 authors, originating from the Netherlands, South Africa, and the Us. Its size is twice that of the earlier volumes in the series. Its approach is scholarly and duly referenced as to notes and bibliography.

Aiming at a more popular audience is the book by Bas Kromhout, confusingly also titled Goede Hoop, with a subtitle in which the 400 years mentioned as covering the relationship make for a catchy title, but are historically wrong - as it was only in 1647 that a group of shipwrecked Dutch settled semipermanently on the Cape. In 1652 Jan van Riebeeck arrived with a voc instruction to found a stronghold. The Europeans never left. The voc lasted till 1795 when the British took over.

Kromhout's book refers to the Rijksmuseum exhibition, but first and foremost accompanies the similarly named television series, in seven installments, made by the Dutch Educational Television organization NTR. In the Rijksmuseum volume, beautifully illustrated, about half of its contents concerns the developments until 1795. Attention is given to the original inhabitants of the Cape area, the Khoikhoi and San. They were slowly pushed back, often with violence, and their land confiscated. Van Riebeeck's status as a role model 
is qualified-as so many protagonists in South African history were and are in need of re-evaluation. The Cape settlement developed into an agriculture colony with free colonists (vrijburgers), who made extensive use of slaves imported from Africa, India, and Southeast Asia. By 1795 the number of slaves surpassed that of the vrijburgers. Throughout the voc period there were clashes with the Khoikhoi and San, who invariably lost, and were the victims of voc genocide, and the Xhosa, who put up more resistance. The vrijburgers developed their own identity, migrated to Xhosa lands and came to call themselves Afrikaners. They asserted, partly by force, their own self-declared rights, which were founded in their religious beliefs and racial theories. Separate chapters are devoted to the influx of Muslims from the Indies, partly exiles, with Sheikh Yusuf as their revered leader until today. The activities of army officer Robert Jacob Gordon (1743-1795) are appropriately highlighted. He made long trips to the interior and collected all kinds of artifacts, made extensive notes, produced meters-long maps and made drawings. Mystery surrounds Gordon's activities around 1795, when the British occupied the Cape, which caused Gordon to commit suicide. Kromhout tells his story as a travelogue, starting in Cape Town (Kaapstad) in 1652. He chronologically moves with the Europeans ever more in the interior, meeting the Khoikhoi and San, and next the Xhosa. He visits historical places, and the museums and monuments that often reflect a partisan view of history. The illustrations are as lavish as in the Rijksmuseum volume.

The greater halves of both books deal with the turbulent events of the last 20o years, with bloody confrontations between British, Afrikaans-speaking settlers (Boers), and indigenous peoples. The Boer Wars (1880-1881 and 18991902) are given a lot of attention, as well as the slow development thereafter of segregation, with its own infamous term: apartheid. The close consanguinity between the Boers and the Dutch was fostered and maintained until the 195 os. Then, with the strong and mounting condemnation of apartheid, matters changed. The strong anti-apartheid movement in the Netherlands was a vocal part of the worldwide indignation that contributed to the release of Mandela in 1990 and his electoral triumph in 1994.

Evelien Pieterse, Sporen van smaragd. Per trein door Nederlands-Indië. Zwolle: WBooks, in collaboration with Spoorwegmuseum, 144 pp. ISBN 9789462582118. Price: EUR 24.95 (hardback).

150 years ago, in 1867 , in Semarang the first train in the Indies steamed to its destination, 25 kilometers away. It was comparably late, but soon railways were opened on Java and Sumatra, especially after 1878 when the government 
assumed the considerable risk and high costs of construction in difficult terrain. Railways, in different gauges, facilitated production and trade, first and foremost for the plantations, but also for the common Javanese. And the KNIL army was quickly on the spot to quell unrest... Ultimately lines extended to 5400 kilometers on Java and 2000 kilometers on Sumatra. To operate the 5500 kilometers of State Railways in 1930 45,000 personnel were employed. The Dutch prided themselves with these railways, generally seen as the symbol of progress.

The Dutch Railway Museum in Utrecht arranged an exhibition to commemorate these 150 years, based on its extensive collection of photographs, models, printed material, and paraphernalia. This book accompanies the exhibition but is not an exhibition catalogue. The emphasis is not on the technical aspects, although these are often referred to, but on the humans operating the trains, as well as the passengers and their train experiences. A closing chapter shows the train as an instrument in and victim of the colonial wars. Its large format and excellent technical care make this book a feast for the eyes. The book is not solely an album of photographs. The captions, sometimes quite extensive, are based on solid research, and add to understanding and enjoyment of the pictures.

Gianni Orsini, Nieuw licht. Het Indisch impressionisme van Bleckmann. Amersfoort: Moesson; Arnhem: Museum Bronbeek, 2017, 120 pp. IS BN 9789070301682. Price: EUR 19.95 (hardback).

Wilhelm Christiaan Constant Bleckmann (1853-1942) was born in Batavia, studied law in the Netherlands, and returned to start a career in the colonial administration (1872), which was interrupted by sick leave. During his stay in the Netherlands (1877-1880) he attended the Amsterdam Academy of Fine Arts and obtained a teacher's degree in drawing. Back in the Indies he taught drawing at secondary schools, gave courses, and painted. After another sick leave he retired and left the Indies in 1898, never to return. He brought with him a great number of paintings with an Indies subject, mainly landscapes. In The Hague, he became a respected person, involved in many artistic circles. His work was generally praised, and exhibited regularly. After his death, his daughter watched over his legacy comprising 68 paintings, which at last was donated to Bronbeek Museum. Bronbeek thus holds the great majority of his Indies works. From May to September 2017, commemorating the seventy-fifth anniversary of Bleckmann's death, Bronbeek staged, after almost half a century, a solo exhibition of Bleckmann's work, with an accompanying book—not a 
catalogue - by Gianni Orsini. Orsini characterizes Bleckmann as a transitional painter who stood, as a combination of a self-taught and an academic artist, at the introduction of modern art concepts in the Indies. He is situated between romanticism and impressionism, between the Netherlands and the Indies, between the nineteenth and twentieth centuries. He was a commendable pioneer, who deserves his central role in the Bronbeek collection and in the development of Indies painting. This all is ably described and analyzed by Orsini, and amply illustrated in oblong format by pictures of Bleckmann's works.

Rob van Vuurde, Adoe Toean Blanda, U staat schaakmat!: Een geschiedenis van het schaken in Nederlands-Indië. Rotterdam: Calbona, 2017, 329 pp. ISBN 9789492575395. Price: EUR 24.95 (paperback).

The history of sports and games in the colonial Indies has only recently attracted attention, which has resulted in a few articles on football. A few memorial volumes were published at the time, as well as sports journals. Recently by way of www.delpher.nl a mass of Indies newspapers have become accessible and may be systematically searched for relevant data. On the basis of these sources, retired historian Rob van Vuurde has written a solid (with 800 references) book on the history of organized chess in the Indies, which started in 1896 with a chess club in Surabaya. Van Vuurde opens with two chapters on the colonial society, with its racial distinction between the Europeans, mainly Dutch, the Chinese, and the natives. Around 1900 great changes set in, the modern times entered, with economic growth, a traffic revolution, the influx of European women, Ethical Policy and nationalist consciousness, but also stronger racial segregation. The time was ripe for organized chess, but it took until 1915 before the Nederlandsch-Indische Schaakbond (NISB) was founded. It suffered from two general disadvantages. The great distances in the archipelago made, even on Java, the organization of chess events difficult and costly. To this may be added the frequent transfer of European officials and employees, which jeopardized the continuity of the NISB and the chess clubs. In 1916 the NISB first issued a journal, Tijdschrift van den NederlandschIndischen Schaakbond, which maintained, with ups and downs, regular publication until 1941-a treasure trove for the historian of the NISB. The first clubs and the NISB were open to all Indies residents. But it was a predominantly Dutch affair-in language and meeting place, for instance, as well as in costs. There was a clear cultural barrier. The benevolent Dutch attitude, characteristic of the Ethical Policy, inspired the NISB to write — and Van Vuurde quotes 
this statement on his title page - that chess needs to be promoted in all layers of the Indies society, as it sharpens and ennobles the mind and thus will contribute to uniting all nationalities in tolerance and mutual appreciation. Within its clubs NISB held high this ideal. It did not prevent the foundation of Chinese and Indonesian chess clubs, which for a part affiliated with the NISB. However, there were a number of clubs which chose to remain outside the NISB. To what extent this was the case is unclear-as Van Vuurde did not find data on this, nor was he able to consult Indonesian-language sources.

A phenomenon that received a lot of attention was the variant of chess played in the Batak regions of North Sumatra, where chess was an important feature of the regional culture. Dutch chess players were fascinated, and tried to document the unwritten rules of Batak chess. In 1914, the Batak champion Si Narsar was invited to Medan and put to the test in 'western' chess. He passed, and he and some of his Batak colleagues toured Java and even played against later world champion Max Euwe in 1930 in a simultaneous display. The NISB prospered after its founding, with a membership rising to almost 30 clubs and 6oo-8oo men in the twenties. It organized the yearly NISB contest, that produced the informal Java champion. The NISB did not succeed, until very late, in organizing an All-Java competition between clubs.

Van Vuurde gives a detailed account of the history of the NISB and its affiliated clubs. He intersperses his text with biographies of prominent chess players and board members. Two familiar names thus appear. J.H. Ritman, the journalist, was chairman of the NISB Board from 1930 until 1941, and W.F. Wertheim, who was considered the strongest player of the Indies in the thirties and won the NISB contest four times. The book also includes the notation of sixty chess games and many illustrations. A separate chapter is devoted to the visit of Max Euwe, which generated a lot of publicity. His schedule was tight - in six weeks he played against 663 opponents in simultaneous displays, and scored an impressive $91 \%$. The crisis of the thirties also affected the NISB: members resigned, clubs dissolved, or went on outside NISB. Was this also caused by uneasiness with NISB of these clubs which might have been Chinese or Indonesian? Suggestions to accommodate possible discontent by issuing a Malaylanguage version of the journal, or nominating an Indonesian to the NIS B board were quietly disregarded. As for the participation of Chinese and Indonesians in the official NISB contests, there was not much to complain about. In the later thirties, they dominated. After the first shock caused by the German occupation the Indies society recovered, and also chess life started again. But not for long, as the Japanese occupation halted all European chess activities. Recovery after 1945 was slow and fragmentary. Dutch soldiers were involved, as well as survivors of the war years. However, the NISB was not resurrected. In 1950, an 
Indonesian Chess Association was founded. In its clubs some Dutchmen were active, but they successively left. Van Vuurde implies that his history is not complete, as he could not consult sources on the non-NISB chess life of Chinese and Indonesians. In his bibliography, he lists two titles in Indonesian, but these are not discussed. The one by F.K.N. Harahap, Sejarah catur Indonesia (1986) seems to offer a lot, but of its almost 500 pages only 33 concern pre-1942 chess life, and half of these consist of party notations. The roles of Si Nasar and Euwe are highlighted. The questions of Van Vuurde about chess outside the umbrella of NISB are not even raised by Harahap. And a search to find more chess history books in the Indonesian language does not result in a single title. Maybe contemporary Indonesian journals and newspapers may supply bits and pieces, but that prospect is not bright. Van Vuurde probably has covered the fieldand his efforts are worthy of praise.

Martijn Kitzen, Oorlog onder de mensen. Militaire inzichten uit Atjeh en Uruzgan. Amsterdam: Ambo/Anthos, 2016, 38o pp. IS BN 9789O26337529. Price: EU R 24.99 (paperback).

In December 2016, Martijn Kitzen (1978) defended his PhD thesis The Course of Co-option: Co-option of Local Power-Holders as a Tool for Obtaining Control Over the Population in Counterinsurgency Campaigns in Weblike Societies, With Case Studies on Dutch Experiences During the Aceh War (1873-c. 1912) and the Uruzgan Campaign (2006-2010). A Dutch-language version was published at the same time with the more succinct title: Oorlog onder de mensen. It is not clear what the differences, if any, are between the two editions. It would have been helpful for Kitzen to supply some information on this matter.

Now a teacher at the Dutch Defense Academy, Kitzen has a background as an officer in the Dutch army, and experience in Afghanistan when NATo put the Dutch army in charge of restoring state authority in the remote province of Uruzgan (2006-2010). He was involved in formulating military tactics to make this mission successful. This asked for a drastic reevaluation of commonly held opinions among the military. The confrontation between two regular armies made place for a 'war amongst the people' (oorlog onder de mensen); essential was support and trust from the population, which could only be obtained by a policy based on profound knowledge of local circumstances, and a well-considered choice of influential allies - as well as foes. He advocated a subtle use of military, political, and economic rewards and sanctions to ensure lasting success. As it lacked continuity, the Uruzgan mission failed when the Dutch left. In essence the mission was a counterinsurgency operation, and past 
experiences within the Dutch colonial empire and by other western powers served as lessons to be learned and adapted.

Kitzen has written a commendable 6o-page account of recent Afghanistan history - the general picture, as well a detailed report on the situation in Uruzgan, with a firsthand analysis of Dutch policies based on his position as both a participant in and architect of those policies. Kitzen's choice to compare the Dutch experiences in Uruzgan with the Aceh War (1873-1912) is not an obvious one, but turns out to be fruitful.

The Aceh part of his book (13o pages) is a fine survey of the complex conflict that lasted four decades, adding enlightening analysis, and using concepts from the counterinsurgency that he discusses at length. He argues that the basic reason the Dutch failed to annex Aceh was their lack of intelligence on the organization of Acehnese power, resulting in counter-productive effects. The role of the Sultan was misinterpreted, and a disastrous coalition with Teuku Umar ensued. It was only the insight of Snouck Hurgronje, who advised the Dutch colonial government, and who was supported by General Van Heutsz, that led to the pacification of Aceh. Snouck's advice was at last followed, based on his analysis of Aceh society and the roles of the Sultan, the religious scholars (ulama), and the local rulers (ulëëbalang) in it. He rightly bet on the ulëëbalang, and secured their allegiance, after a show of Dutch military power, by a system of rewards and sanctions. Snouck's lessons were learned, but in Kitzen's analysis, during the last decades of Dutch colonial rule these were not properly applied, and this military failure helped to enable the Indonesian Revolution.

Kitzen has some advice for the Dutch military concerning the issue of counterinsurgency. Do a lot of research on the conditions in the area of deployment, create policies made to measure, and have patience to await positive results that will be slow in coming. As the Afghan War continues in its sixteenth year with no end in sight, positive results are indeed slow in coming.

Given his insights on Uruzgan, along with the breadth of his experience as both a scholar and a soldier, I wondered about his perspective on that other great colonial conflict the Dutch were involved with: the Decolonization War of 1945-1949. How do his counterinsurgency concepts apply to this conflict? Curiously, Kitzen does not mention this war, even in passing. Why was it omitted? I can only think of reasons of space, but a few lines acknowledging it would have been useful. 
Freark J. Beuckens, Deiboek fan in Fryske soldaat yn Yndië, 1947-1950. Edited by Popke Popma and Tsjerk Veenstra. Ljouwert: Afûk, 2017, 432 pp. ISBN 978949217653o. Price: EUR 24.95 (hardback).

In Soldaat in Indonesië 1945-1950, Gert Oostindie uses 659 personal documents by participants on the Dutch side in the Decolonization War to analyze Dutch soldier's lives in Indonesia. The candid diary by Freark Beuckens is unique among all these sources, as he relates his experiences in the Frisian languagethe only such one known. His diary was not completely unreferenced, however, since Hylke Speerstra's Op klompen troch de dessa (2015) (translated into Dutch as Op klompen door de dessa (2015); 'On clogs through the village'), which was mainly a collection of interviews with Frisian veterans, was the first to include excerpts from Beuckens' diary. Freark Beuckens (1926-1974) was drafted in November 1946, and thus left his home village Nijemirdum in Southwest Friesland, where he worked as a farm-hand after his primary school education. In September 1947 he embarked to the Indies, as member of the 4th Company Air Force Troops (Luchtvaarttroepen), whose main task was to keep guard of airfields. Beuckens was an intelligent observer, and decided already during the sea journey to keep a diary, which he kept from August 24, 1947 until March 22, 1950. He illustrated his writing with 700 photographs. Of these about 160 are included in this book. Beuckens nowhere discloses why he decided to keep a diary. After he returned he married his fiancee-both faithful to the promise they made to each other before he left. To her and their four children he never spoke about his Indonesian years, and his diary was stored away. Only after his death, and by chance, was the diary rediscovered. It took a lot of time and labor to produce this book.

In Indonesia, Beuckens was encamped in and around Jakarta and Bandung until September 1949, and thereafter until the home journey his base was Semarang. In particular in the Bandung period he was involved in active patrolling, and discusses a number of outrages which violated the rules the Geneva Convention. In general, however, his tasks were monotonous and boredom often reigned supreme. He noted the lack of information, the absence of education, and the swift realization that the Dutch were on an impossible mission. As to the political developments the common soldier, including Beuckens, did not know anything, but based on his own experiences his opinion of Indonesians was negative and patronizing. Erotic relations between military and Indonesian women were a regular feature. Boredom became even stronger after the cease-fire of August 1949, with transfer of territory and facilities to the Indonesian army. And after December 27, 1949 the Dutch soldiers, waiting for the boat to bring them home, could only be patient and keep a low profile. 
Regarding the editorial care: a short biography of Beuckens is added, as well as a ten-page summary of the conflict. A list of Malay words is added, which unfortunately contains some errors. In all, this is a fine tribute to a young soldier who lost his innocence in the Indies, and who remained bitter as he felt that he was let down and was sent to Indonesia under false pretexts.

Marianne Janssen, De soep ruikt naar hond. Herinneringen van Indische Nederlanders, hun kinderen en kleinkinderen na de oversteek naar Holland. Meppel: Just Publishers, 2017, 256 pp. ISBN 9789089750983. Price: EUR 19.95 (paperback).

The Japanese occupation of the Indies and the decolonization war upset a colonial society. The Indonesian Republic won after a bitter struggle. Among the victims were the Indo-Europeans, or 'Indische Nederlanders', who lost their privileged intermediate position, and had to choose between loyalty to their Indonesian and Dutch roots. In the end, also because the Indonesians had made clear their antipathy towards the Indo-Europeans, the great majority opted for a Dutch passport and to 'repatriate' to a country most of them had never visited before. All Dutchmen were expelled until 1957, and altogether an estimated 300,00o people left Indonesia. They were not welcomed heartily in the Netherlands, but with hostility and suspicion. Initially, in the first reviews of the Indies immigration waves, the Dutch authorities and welfare organizations were praised for their smooth handling of the influx, which led to a swift integration of these Indonesian-Dutch. Already for a number of decades there has been an abundance of publications available, from those involved or with a scholarly focus, that have disputed this one-sided image. Retired journalist Marianne Janssen (1947), herself not with an Indies past, has written the life stories of a small number of Indies families after their departure, based on interviews with and letters of about fifteen informants, as well as existing accounts. These are often the experiences of young children, born in the forties, supplemented by the search for a new life of the first generation, and discovery of the Indies roots of the third generation. Janssen approaches her subject thematically, which works quite well. Thus, after a background chapter on the Japanese occupation and the choice to relocate to the Netherlands, a shameful litany of discrimination and prejudice follows, with a greedy government squeezing the destitute community of Indonesian Dutch out of what little money they had. Housing was abominable, and patronizing officials educated the women on how to organize a household and how to cook a Dutch meal. As for jobs the men were discriminated against, and their competence was doubted. At 
school the plight of Indonesian-Dutch children was not to be envied. Only in the safety of their own community could they find sympathy and understanding, and there, along with the Indies food, nostalgic memories were cherished. For the rest, it was accommodation that set the tone. This well-written book, with its many personal details, is a fine addition to the many accounts about the roots and remnants of the first postcolonial communities of Indonesian Dutch in the Netherlands. 